\title{
Terms of marriage and time-use patterns of young wives: Evidence from rural Bangladesh
}

\author{
Sajeda Amin \\ Population Council \\ Luciana Suran
}

Follow this and additional works at: https://knowledgecommons.popcouncil.org/departments_sbsr-pgy

Part of the Demography, Population, and Ecology Commons, Family, Life Course, and Society Commons, Gender and Sexuality Commons, and the International Public Health Commons How does access to this work benefit you? Let us know!

\section{Recommended Citation}

Amin, Sajeda and Luciana Suran. 2008. "Terms of marriage and time-use patterns of young wives:

Evidence from rural Bangladesh," Poverty, Gender, and Youth Working Paper no. 10. New York: Population Council. Version of record: dx.doi.org/10.13085/elJTUR.6.1.92-108 


\section{POVERTY, GENDER, AND YOUTH}

Terms of Marriage and Time-Use Patterns of Young Wives: Evidence from Rural Bangladesh

Sajeda Amin and Luciana Suran

WORKING PAPER NO. 102008

$\mathcal{Q}$ Population Council 


\section{(1) Population Council}

One Dag Hammarskjold Plaza

New York, New York 10017 USA

www.popcouncil.org

pubinfo@popcouncil.org

For information on Poverty, Gender, and Youth working papers, see www.popcouncil.org/publications/wp/index.html

This material may not be reproduced without written permission from the authors.

ISSN: $1554-8538$

(C) 2008 The Population Council, Inc. 


\title{
Terms of Marriage and Time-Use Patterns of Young Wives: Evidence from Rural Bangladesh
}

\author{
Sajeda Amin \\ Luciana Suran
}

Sajeda Amin is Senior Associate, Program on Poverty, Gender, and Youth, Population Council, New York. E-mail: samin@popcouncil.org. Luciana Suran is Consultant, Population Council, New York.

This paper was made possible through support provided by the Department for International Development, U.K. (DfID); the Mellon Foundation; UNICEF, Dhaka; and the Office of Population and Reproductive Health, Bureau for Global Health, U.S. Agency for International Development, under the terms of Award No. HRN-A-00-99-00010. The opinions expressed herein are those of the authors and do not necessarily reflect the views of the U.S. Agency for International Development. Statistical advice from S. Chandrasekhar is gratefully acknowledged. 


\begin{abstract}
This paper explores the relationship between marriage arrangements and daily activities of young married women, using detailed time-use data from an adolescent study in rural Bangladesh. Measures of marriage arrangement are payment of dowry and the relative wealth status of natal and marital families. The data were collected in three rural districts in 2001 and 2003. Using multivariate regression analysis, the results show that women's time spent in domestic work, socializing, and self-care is significantly associated with marriage arrangement variables. Those who paid dowry spent more time in domestic work and less time in self-care and socializing relative to those who did not pay dowry. These patterns of association are similar to those the authors found in an earlier study between marriage arrangements and domestic violence, where paying dowry and marrying up are associated with greater violence.
\end{abstract}


Families in rural Bangladesh invest heavily in the marriages of daughters as a way of ensuring their daughters' well-being. Making a good match often receives priority over a good education or investments in human capital that would lead to success in the labor market (Mahmud and Amin 2006). A good marriage is the outcome of many factors besides educationfamily wealth, good reputation, good connections, and the availability of suitable grooms and funds for dowry (Amin and Cain 1997). This paper follows on earlier work by the authors to explore how well these marriage investments deliver on the promise of a good life for young women after marriage.

Contrary to expectations of the bride's family that dowry (marriage payment made to the groom and his family by the bride's family) will ensure better treatment of girls in marriage, Suran, Amin, Huq, and Chowdhury (2004) found that the payment of dowry is associated with an increased likelihood of domestic violence in the early years of marriage. They found the relationship to be non-linear: while it is true that among those who pay dowry, more dowry is associated with less violence, marriages that take place with no dowry are associated with less violence than those that involved the highest dowries.

By exploring a detailed data source on young women's time-use patterns in conjunction with detailed data collected on their marriage arrangements, we shed light on the more general relationship between marriage arrangements and marital well-being. We analyze time-use data based on 24-hour recall to determine the amount of time spent in domestic work, self-care, productive work, and social time in relation to marriage variables and other background variables. Our objective is to understand the implications of marriage decisions for the day-today lives of young married women. If dowry is indeed a way to ensure a daughter's well-being in her marital home, as many families assume (Amin and Huq 2008), then more dowry should be associated with more social time, less work, and more rest. Hypergamy, or marrying a groom from a wealthier family, would produce similar outcomes. Because a groom from a better-off family is more desirable, all else being equal, hypergamy is associated with greater dowry paid (Rao 1993).

There are relatively few examples of detailed analysis of time-use data in developingcountry settings. One comprehensive review of available time-use studies (Ilahi 2000) concludes that such data are particularly important for understanding dynamics when nonmarket economic activities are significant determinants of well-being. In many parts of the world women's childrearing and domestic activities fall into this category. Studies of time use that focus on the length of the workday find substantial differences in time-use patterns by age, gender, and socioeconomic status (Cain 1977; Cain, Khanam, and Nahar 1979). Time-use studies have been crucial in understanding gender differences in work patterns and women's domestic responsibilities and in explaining gender differences in labor market participation across societies. For example, comparisons across four rural communities in South Asia documented significant variation in women's involvement in agricultural work and showed substantial domestic work burdens for women in all communities (Jain 1985).

Much of this analysis of time use focuses on productive work, with all forms of leisure as a residual category. Larson and Verma's (1999) review of time-use literature points to the importance of studying patterns of leisure time as it relates to more productive outcomes-for example, the consequences of time spent in organized sports and with friends for outcomes such 
as school performance. These issues primarily pertain to unmarried adolescents. While this literature suggests that it is important to explore the finer points of leisure time and its nature, it offers little by way of understanding leisure as an indicator of quality of life per se or what the implications may be for married adolescents.

Examining variations in the nature of time use as a reflection of status is a major preoccupation of leisure studies (Katz-Gerro 2002, 2004). Gender differences in leisure time are also analyzed to understand differences between men's and women's patterns of cultural consumption and time spent in sports in addition to status attainment generally (Jackson and Henderson 1994).

The promise of comparing time use among women with different life experiences as a quality-of-life measure, specifically as an indicator of empowerment, finds support in the women's status literature (Basu and Koolwal 2005). Analysts increasingly recognize that status has multiple dimensions. While it is common to measure status using knowledge and attitude variables related to contributions to the household and other forms of altruistic behavior, or behaviors that make women more productive or functionally useful, there is increasing recognition that taking care of women's own needs may have important implications for women's status as well, particularly as a determinant of their health (Agarwal 1997). Basu and Koolwal (2005) argue that self-indulgence, the ability to act in ways that serve women's own needs, has particular benefits for women's well-being. Using activity prompts that indicate such leisure activities as reading the paper, listening to the radio, and watching television, they find these variables to be associated with better health outcomes. They find that self-indulgent variables - which they also label "unproductive freedoms" - stand in sharp contrast in their association with women's own health status to variables that indicated women's responsible behavior toward others. They interpret these associations not as causal but rather as related to factors such as good status in the household and control over resources that lead to more selfindulgent behaviors on the one hand and better health on the other.

We explore correlates of time spent in two types of self-indulgence-social time and selfcare - in addition to productive and domestic work, as measures of the post-marriage domestic environment. Our measure of social time includes visiting friends and relatives and captures some aspects of social networking and freedom of movement. Our experience in rural Bangladesh, particularly our observations of the severely circumscribed lives of young, married women, does not lead us to expect much variability in this measure across a sample of recently married women. Rather we focus on activities that we label self-care, including time spent resting (whether sick or otherwise, but not sleeping), bathing, and grooming. In the way we categorize our data, self-care is leisure time that is spent alone, and some aspects of it such as personal grooming may be interpreted as culturally sanctioned leisure activity that has connotations of self-indulgence.

When a young bride first enters her marital home, the restrictions on her social interactions increase even as her social networks shrink to little more than her immediate family members. She is expected to spend her time learning her new roles in running the household and doing her share of domestic activities. It is generally considered inappropriate for a young bride to talk, play, or socialize with neighbors. However, a caring husband or mother-in-law might indulge a young bride by allowing her extra time to rest or groom herself. These indulgences are 
indicated by family members buying her hair oil and fragrant soap or cosmetics. Even among women who are thus indulged by family members, however, whether a new bride actually spends time grooming herself, we hypothesize, depends on the extent to which she is confident about her status in the marital household and reasonably assured that such behaviors will not reflect poorly on her upbringing and be frowned upon.

\section{DATA AND Method}

As part of a project on adolescent livelihoods, ${ }^{1}$ survey data were collected in 2001 and 2003 from female adolescents aged 13-21 who were chosen randomly from 90 villages in three districts of rural Bangladesh. In 2001, 2,386 female adolescents were contacted successfully and completed the initial interviews. During a follow-up survey conducted from January to June 2003, 2,214 of the original female respondents were contacted and re-interviewed. ${ }^{2}$

Detailed time-use data were collected as part of the questionnaire, which included information on individual and family variables. The data were collected for the day prior to the interview using a sequential recall of activities. Sixty-eight types of activity were later classified into productive work, domestic work, self-care, social time, and sleep. Interviewers recorded the starting and ending time of each activity, and this information was later converted into hours and minutes.

We limited our sample to currently married women $(\mathrm{N}=1,278)$. Time-use data were taken from the 2003 survey, while data on background characteristics such as marriage, education, and parental characteristics were first collected in 2001 and updated, when relevant, in 2003. The questionnaire also included detailed information concerning the circumstances surrounding marriage, including dowry, marriage timing, and the characteristics of husbands' and natal families.

The regression results are interpreted only in associational rather than causal terms. We present regression results from models in which the proportion of time spent in different time-use categories is represented. We compared these results with those of Tobit models where the total amount of time rather than the proportion of time was estimated. The two methods yielded identical results in terms of the signs and significance of coefficients.

We realize that factors unobserved in the data may determine both marriage arrangements and time-use patterns. Qualitative data from a study in northern Rajshahi suggests that factors such as a compromised family situation, bad reputation, volatile temper, or disability may result in a deleterious marriage arrangement with negative consequences for women's well-being after marriage (Amin and Huq 2008). To test for the existence of such a selection effect, we estimated a Heckman selection model using the full sample and the restricted sample (interim marriages taking place between 2001 and 2003). The selection equation reflected whether dowry was paid, and the explanatory variables were age at marriage, wealth of bride's household, and bride's education. The likelihood ratio test for independence of the two equations (selection equation and time use) revealed that the two equations were independent. In light of this result, we are justified in estimating only the time-use equation and including dowry payments as an explanatory variable. 


\section{RESULTS}

Table 1 contains data on the variables used in the analysis. Since the original sample was adolescents aged 13-21 in 2001, the study is limited to young married women. The mean age of the respondents was 20.4 years in 2003 . The mean age at marriage for the sample is 15.3 years (data not shown), and more than 75 percent of respondents had ever attended school for an average of 4.7 years. About 40 percent were married into families of similar status as their natal family, and approximately 34 percent and 26 percent of respondents married up and down respectively. Three-fourths of marriages involved a dowry payment, which averaged about 9,849 taka. ${ }^{3}$ On average, the respondents have 1.2 children. The regional distribution of this sample of married women is influenced by the age patterns of marriage. Since age at marriage is generally later in Chittagong district, a lower proportion is from that district.

Wealth inequality between families in marriage is a variable of interest in the analysis, and since relative wealth is correlated with absolute wealth measures, we did not include any other wealth measure in the model. Wealth status of natal and marital families was calculated from a list of possessions. Households were then categorized into quintiles according to the resulting asset index, and the relative ranks of natal and marital households were compared. This manner of calculating relative wealth leads relative wealth to be highly collinear with absolute wealth ranking. Accordingly we have not included absolute wealth rankings in the models.

Dowry was also introduced as a relative rather than an absolute measure and was adjusted for inflation using the price of rice as a deflator (Amin and Cain 1997). Five categories of dowry payments were defined, with no dowry used as the reference category. Among those who paid dowry, respondents were categorized into relative dowry quartiles within their district. Dowry was measured as a district-specific variable because marriage markets and practices are local, and the overall level of dowry varied considerably from district to district.

Other variables considered are respondent's age, her years of education, and the number of children borne by the respondent.

We ran multivariate regressions using percent of time spent in the various activity categories as the dependent variable. Measuring childcare is difficult particularly when it is not for pay and is provided by a caregiver who looks after a child throughout the day. Most women do not report childcare as a simultaneous activity with cooking or cleaning, which might take precedence in reporting. Our measure is more likely to identify episodes such as bathing and feeding a child when it is being done as an exclusive or a primary activity. Aspects of childcare that are underreported are watching the child or supervising schoolwork or play.

Before presenting our results, we mention several caveats. Most importantly, although we use causal models, we acknowledge that many of the behaviors we consider are determined by common factors. The same factors that determine marriage arrangements may also determine time use. Our purpose is not to suggest causal models but to demonstrate how variables are grouped together to form patterns. Second, although the sample is drawn from a cohort of women 23 years or younger, we expect this to be a relatively small bias given the very early age at marriage in Bangladesh and the high proportions of girls who are married by the age of 19.

The five categories of time use examined are domestic work, productive work, self-care,

social time, and sleep. ${ }^{4}$ The list of activities included in the first four categories appears in 
Appendix 1. All respondents reported some time spent in sleep, self-care, and domestic work. Only 72 percent reported activities that we classify as socializing, and 40 percent reported activities that we classify as productive work (data not shown). ${ }^{5}$

\section{Social time}

We define social time as any time spent playing, visiting, attending a social ceremony, or hanging out with friends and relatives in the absence of other activities. Such activities account for only 6 percent of married women's time in the 24-hour recall period. Participation in such activities varies within the three study areas and is more common in the less conservative areas. In the context of rural Bangladesh, these are bolder ways for young, married women to indulge themselves and thus are qualitatively different from self-care in how they should be interpreted.

Coefficients associated with covariates of social time estimated from multivariate regression analysis are shown in Table 3. Our estimates show that young women spend significantly more time socializing time in Chittagong and Sherpur relative to Chapainawabganj. Social time decreases significantly with current age for married women and increases with their level of education. Social time also increases with the number of children a young women has. This increase in social time may be associated with a relaxation of restrictions on women's mobility as she becomes older, either because of her maturity or because she has become a mother. However, social time does not seem to be associated in a significant way with variables indicating marriage arrangements. Neither the relative wealth of natal and marital families nor level of dowry payments is significantly associated with the amount of social time reported.

\section{Productive work}

Table 4 shows regression coefficients associated with covariates of productive work. As in the case of social time, only 6 percent of total time reported was spent in productive work (Table 2). Our data confirm that productive work is not a major preoccupation for young married women in rural Bangladesh. Only 40 percent of respondents reported some productive work, of which approximately half was done in combination with childcare (data not shown). Productive work increases significantly with age and decreases significantly with education. Productive work decreases significantly with number of children, by far the most important factor associated with productive work. Dowry and relative wealth of the natal and marital families are not significantly associated with productive work.

District of residence is a significant covariate of the percentage of time spent in productive work as reported by respondents. Women in Chapainawabganj spend more time in productive work relative to Sherpur (the poorest district) and Chittagong (the wealthiest and most conservative district). Although Chittagong is also characterized by a higher mean age at marriage, the prevalence of domestic violence and other indicators of women's autonomy suggest that women in that district are less empowered. District is an important determinant pointing to the influence of overall context in explaining individual behavior. Better-educated women report significantly less time spent in productive work, consistent with patterns of decreasing labor force participation with increased education (World Bank 2008). 


\section{Time spent in self-care}

Table 5 shows factors associated with the amount of time women devote to self-care. The average respondent spent 21 percent of the previous day in self-care activities (Table 2). Our knowledge of the local culture leads us to interpret more time spent in self-care, in the presence of appropriate controls, as one of the ways in which a married woman can pamper herself $-\mathrm{a}$ form of self-indulgence. Although such behavior may be frowned upon and it is common for young women to be chastised by mothers-in-law for spending too much time on themselves, these activities are permitted nevertheless. A husband may also express his appreciation of his new bride by buying her fragrant soap, shampoo, and hair oil, so that she may indulge herself with these products. These little rituals also make time spent in self-indulgence a public statement of higher status. Thus, this indicator is perhaps the most sensitive time-related status indicator associated significantly with many of the covariates considered.

In a setting where women's time use is strongly dictated by the needs of the household and by restrictions on their mobility outside the home, taking extra time to bathe, groom, or simply rest is one of the limited ways in which young women can legitimately pamper themselves. Amount of time spent in self-care decreases slightly but significantly with age and increases slightly but significantly with education. Women in Chittagong spend more time in self-care relative to women in Chapainawabganj, and women in Sherpur spend less time in selfcare. Relative to women who married into a household of similar economic status, women who married into a poorer family spend less time on self-care. In this regard hypergamous women are not significantly different from women who married a husband of equal status. Paying dowry is related to less time spent in self-care. Relative to women who paid no dowry, those in the lowest dowry quartiles were not significantly different, but women in the two middle dowry quartiles spent significantly less time in self-care.

\section{Domestic work}

Table 6 shows coefficients associated with covariates of domestic work from multivariate regression analysis. The dependent variable is the percentage of total time in spent in domestic activities during the 24 hours prior to the survey. The average woman spends 29 percent of the day doing domestic chores, and nearly all women reported some domestic activity (Table 2). Domestic work is the only time-use category that did not vary significantly by the district covariate. The amount of domestic work increases with number of children. Relative to women who paid no dowry, those who did so spent significantly more time in domestic work. To the extent that larger dowry amounts are associated with wealth status, this result is consistent with time-use patterns reported in other studies in rural Bangladesh where women in wealthier families have longer work hours, particularly in agricultural households. This is usually because it is uncommon for wealthy landowners to hire help for domestic work even though they might do so for agricultural work (Cain, Khanam, and Nahar 1979; Amin 1997). Rather, when wealthy families hire agricultural workers, the domestic work burden for women in the household increases because they are responsible for preparing food for hired hands, who are compensated in cash and meals. 
Overall, then, relative wealth status of natal and marital families and payment of dowry are not significantly associated with time spent in productive or domestic work, but there is a significant association with social time and self-care. Relative to women who paid no dowry, higher dowry is associated with more domestic work, less time in self-care, and less socializing.

\section{DISCUSSION AND CONCLUSION}

We explored the patterns of association between women's individual and marriage characteristics and the ways in which women spend time. In contrast to productive work, women's allocation of time to self-care and domestic work are more strongly associated with marriage characteristics and may be interpreted as indicators of their quality of life. Like productive work, social time is also not significantly associated with marriage characteristics. One part of this lack of association is that young married women spend very little time in directly productive activities or in socializing. Using dowry payments and relative wealth status as measures of marriage status, we find that women who paid dowry reported more domestic work, less social time, and less time on self-care relative to women who did not pay dowry. These associations between time use and marriage variables were similar to the association we found in an earlier study between marriage arrangements and gender-based violence (Suran, Amin, Huq, and Chowdhury 2004). By contrast, the associations with women's education worked in a diametrically opposite way: better-educated women had more social time and spent more time in self-care and less time in domestic work. If parents pay dowry with the expectation that daughters will lead a better life after marriage, our data do not bear out that expectation.

It is noteworthy that participation in productive work, although varying widely at the district level, was not associated with marriage investments. The pattern of variation at the district level suggests that women's participation in work that is not traditionally considered to be in the female domain is determined more by community norms than by household or individual factors. Women in the less conservative division of Rajshahi, where Chapainawabganj is located, have historically had relatively greater freedom (see Amin, Basu, and Stephenson 2002) and have also engaged in higher levels of productive work relative to women in the more conservative but prosperous district of Chittagong and the poorer district of Sherpur.

Our analysis demonstrates that not paying dowry and educating daughters work in similar ways in terms of their association with time-use patterns. This finding suggests that both factors are related to the ability to break from societal norms and that this ability is probably the latent variable that underlies most of these associations. Although our analysis contributes to the evidence base on marriage arrangements and their outcomes, we have not been able to shed light on a question of central concern in Bangladesh, namely why dowry payments persist and continue to rise when there is no evidence that girls who marry with dowry are better off. However, we have shown here, as well as in our earlier analysis of the covariates of genderbased violence, that whereas women who pay more dowry may fare better than those who pay less, women who pay no dowry are even better off than those who pay the highest amounts of dowry. This evidence points to the need to explore further the characteristics of those marriages that take place with no dowry. 


\section{NOTES}

1 The project, entitled Kishori Abhijan (Adolescent Girls' Adventure), was a UNICEFfunded initiative on adolescent livelihoods implemented by two development NGOs, the Bangladesh Rural Advancement Committee (BRAC) and the Centre for Mass Education in Science (CMES), in three districts of rural Bangladesh. The Bangladesh Institute of Development Studies, in collaboration with the Population Council, conducted a twoand-a-half-year investigation to document the implementation and results of the project. Kishori Abhijan enrolled fewer than 20 percent of the survey respondents because the survey was meant to be a representative sample of adolescents generally and not just of adolescents in the livelihood program. The majority of married respondents did not participate in Kishori Abhijan.

2584 of the 2,386 respondents with whom follow-up interviews were attempted had migrated, mostly owing to marriage. Interviewers were able to reinterview 476 of these respondents because they had relocated elsewhere within the same district.

$3 \quad$ US\$1 = 59 Bangladeshi taka in 2005.

4 The respondent was asked to report all activities she engaged in within the 24 hours preceding the interview. After this listing was completed, she was asked whether a child was in her care during the activities reported. For example, a woman could report childcare during sleep. In fact, a substantial percentage of respondents reported performing childcare during sleep in both 2001 (40 percent) and 2003 (48 percent). Another possibility is that mothers who did not report childcare during sleep may have had relatives or other persons living in the household who also take care of children.

5 Given that many activities in a woman's life are related to subsistence, we used our knowledge of the local economy and previous analyses of time use in rural Bangladesh conducted by Cain (1977), Amin (1997), and others to classify particular tasks around the house as productive. Tasks that are not directly remunerative may nevertheless be thus classified if they represent a cost-saving activity.

\section{REFERENCES}

Agarwal, Bina. 1997. "Bargaining and gender relations: Within and beyond the household," Food Consumption and Nutrition Division Paper No. 27. Washington, DC: International Food Policy Research Institute.

Amin, Sajeda. 1997. "The poverty-purdah trap in rural Bangladesh: Implications for women's roles in the family," Development and Change 28(2): 213-233. 
Amin, Sajeda, Alaka Malwade Basu, and Rob Stephenson. 2002. "Spatial variation in contraceptive use in Bangladesh: Looking beyond the borders," Demography 39(2): 251267.

Amin, Sajeda and Mead Cain. 1997. "The rise of dowry in Bangladesh," in The Continuing Demographic Transition, eds. Gavin W. Jones, John C. Caldwell, Robert M. Douglas, and Rennie M. D'Souza. Oxford: Oxford University Press.

Amin, Sajeda and Lopita Huq. 2008. "Sending girls to school in Bangladesh," paper presented at the American Educational Research Association Meetings, New York.

Basu, Alaka Malwade and Gayatri Brij Koolwal. 2005. "Two concepts of female empowerment: Some leads from DHS data on women's status and reproductive health," in A Focus on Gender: Collected Papers on Gender Using DHS Data, ed. Sunita Kishor. Calverton, MD: ORC Macro, pp. 15-53.

Cain, Mead T. 1977. "The economic activities of children in a village in Bangladesh," Population and Development Review 3(3): 201-227.

Cain, Mead T., Syeda Rokeya Khanam, and Shamsun Nahar. 1979. "Class, patriarchy, and women's work in Bangladesh," Population and Development Review 5(3): 405-438.

Ilahi, Nadeem. 2000. "The intra-household allocation of time and tasks: What have we learnt from the empirical literature?" Policy Research Report on Gender and Development, Working Paper Series No. 13. The World Bank Development Research Group/Poverty Reduction and Economic Management Network. Washington, DC.

Jackson, Edgar L. and Karla A. Henderson. 1994. "Gender-based analysis of leisure constraints," Leisure Sciences 17: 31-51.

Jain, Devaki 1985. "The household trap: Report on a field survey of female activity patterns," in Tyranny of the Household: Investigative Essays on Women's Work, eds. D. Jain and N. Bannerjee. Delhi: Shakti Books, pp. 215-249.

Katz-Gerro, Tally. 2002. "Highbrow cultural consumption and class distinction in Italy, Israel, West Germany, Sweden, and the United States," Social Forces 81(1): 207-229.

-. 2004. "Cultural consumption research: Review of methodology, theory, and consequence," International Review of Sociology 14(1): 11-29.

Larson, Reed and Suman Verma. 1999. "How children and adolescents around the world spend time: Work, play, and developmental opportunities," Psychological Bulletin 125: 701736.

Mahmud, Simeen and Sajeda Amin. 2006. "Girls' schooling and marriage in rural Bangladesh," in Research on the Sociology of Education, Volume 15: Children's Lives and Schooling 
across Societies, eds. Emily Hannum and Bruce Fuller. Boston: JAI Elsevier/Science, pp. 71-99.

Rao, Vijayendra. 1993. "Dowry 'inflation' in rural India: A statistical investigation," Population Studies 47(2): 283-293.

Suran, Luciana, Sajeda Amin, Lopita Huq, and Kobita Chowdury. 2004. "Does dowry improve life for brides? A test of the bequest theory of dowry in rural Bangladesh," Policy Research Division Working Paper No. 195. New York: Population Council. $<$ http://www.popcouncil.org/publications/wp/prd/195.html $>$. 
Appendix 1: Activities recorded in 24-hour time recall

\section{Domestic Work}

Cooking/washing utensils

Cleaning courtyard/house

Collecting water

Collecting firewood

Washing/drying clothes

Repairing house

Drying cow dung for fuel

Attending sick person

Other household work

Breastfeeding

Other intensive feeding

Bathing children

Nursing sick child

Purchasing food and other items

Purchasing non-food items only

\section{Self-Care}

Rest

Bathing, grooming, toilet

Resting while sick

Eating

\section{Social Time}

Playing with child

Playing

Visiting other district

Moving around

Attending social ceremony

Visiting friends/relatives

\section{Productive Work}

Cleaning/weeding/planting/irrigation

Looking after field

Looking after poultry/livestock

Harvesting/carrying crop

Threshing/drying/husking

Selling crop

Collecting vegetables and fruits

Processing harvests

Separating jute fiber

Drying fish

Processing fish

Fishing

Feeding fish

Selling fish

Day labor (agri)

Day labor (non-agri)

Contract labor

Other labor

Cottage industry

Carpenter

Private tutor

Pulling rickshaw/van

Driving motor vehicle

Begging

Repairing farm equipment

Helping business work

Slaughtering animal

Teaching

Moving around for work

Other mechanical work

Tailoring

Cutting tree/bamboo 
Table 1: Distribution of dependent variables, married adolescent women, Kishori Abhijan Survey, Bangladesh, 2001 and 2003

\begin{tabular}{lcr}
\hline & Variable type & Mean \\
\hline Age (years) & Continuous & 20.4 \\
Years of education & Continuous & 4.7 \\
Percent paid dowry at marriage & Binary* & 74.4 \\
Mean inflation-adjusted dowry (Taka) & Continuous & 9,849 \\
Percent with children & Binary* & 75.9 \\
Number of children & Continuous & 1.2 \\
Percent randomly sampled ${ }^{\mathrm{a}}$ & Binary & 87 \\
District & Categorical & \\
Percent from Chapainawabganj & & 44.9 \\
Percent from Chittagong & & 15.7 \\
Percent from Sherpur & & 39.4 \\
Relative wealth of wife's and husband's family (percent) & & \\
Wife $=$ husband & & 40.5 \\
Wife $<$ husband & & 33.8 \\
Wife $>$ husband & & 25.7 \\
\hline
\end{tabular}

* Not included in model — shown for descriptive purposes only.

${ }^{a}$ To ensure that enough respondents would join a program, researchers purposively sampled girls who were thought to be more likely to join (i.e., younger girls with parents who had a history of involvement in NGOs), representing 13 percent of the current sample after allowing for missing information. To control for bias associated with this nonrandom selection in a subset of the sample, a binary variable equaling 1 if the respondent was randomly sampled and 0 otherwise was entered in all models. 
Table 2: Distribution of time spent in broad activity categories during the 24 hours prior to interview, 2003, married women only

\begin{tabular}{lc} 
& Percent of time spent \\
\hline Social time/leisure & 6 \\
Productive work & 6 \\
Self-care & 21 \\
Domestic work & 29 \\
Other, including sleep & 38 \\
\hline
\end{tabular}


Table 3: Coefficient estimates from regression analysis of time spent in social activities, Bangladesh, 2003

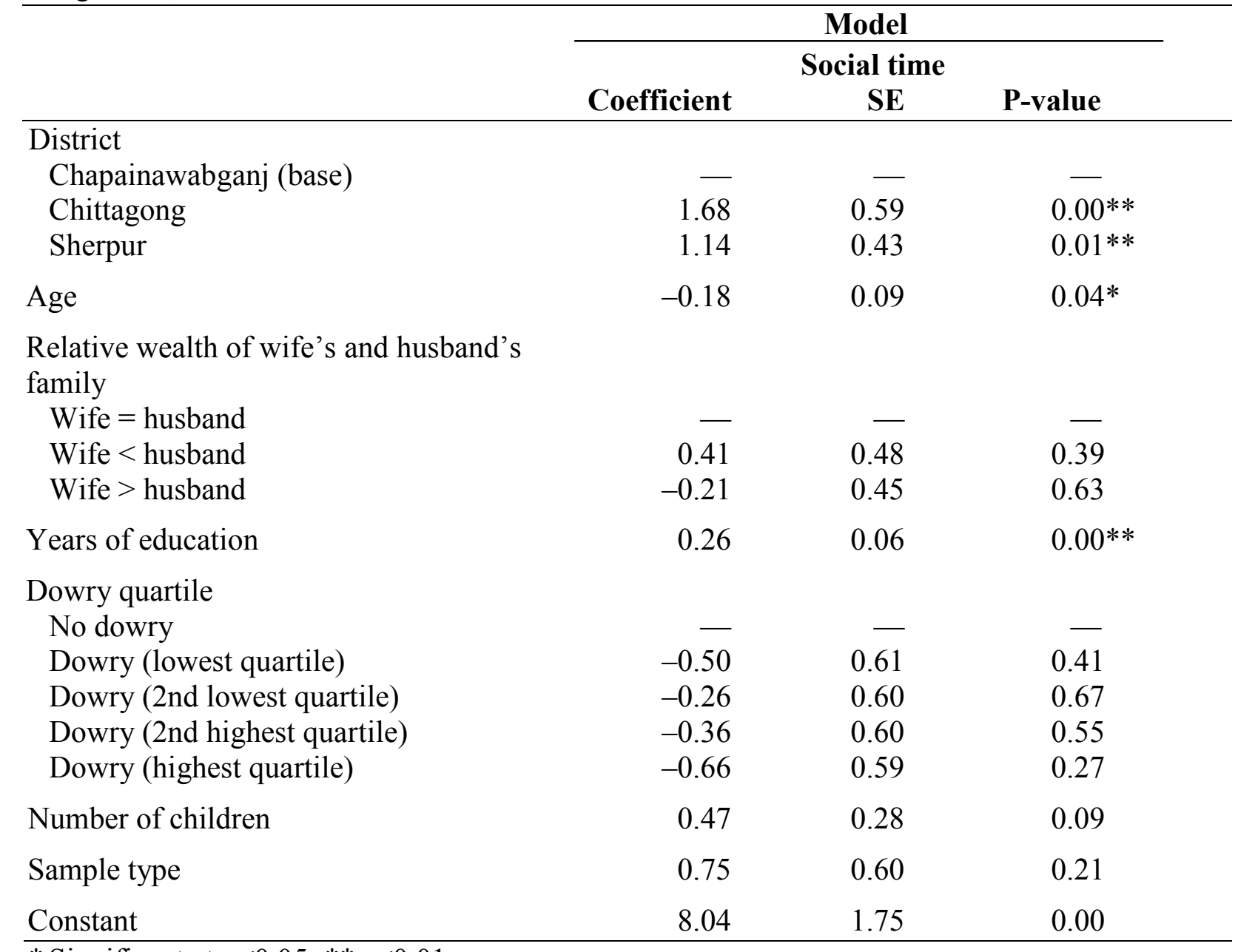

* Significant at $\mathrm{p} \leq 0.05 ; * * \mathrm{p} \leq 0.01$. 
Table 4: Coefficient estimates from regression analysis of time spent in productive work, Bangladesh, 2003

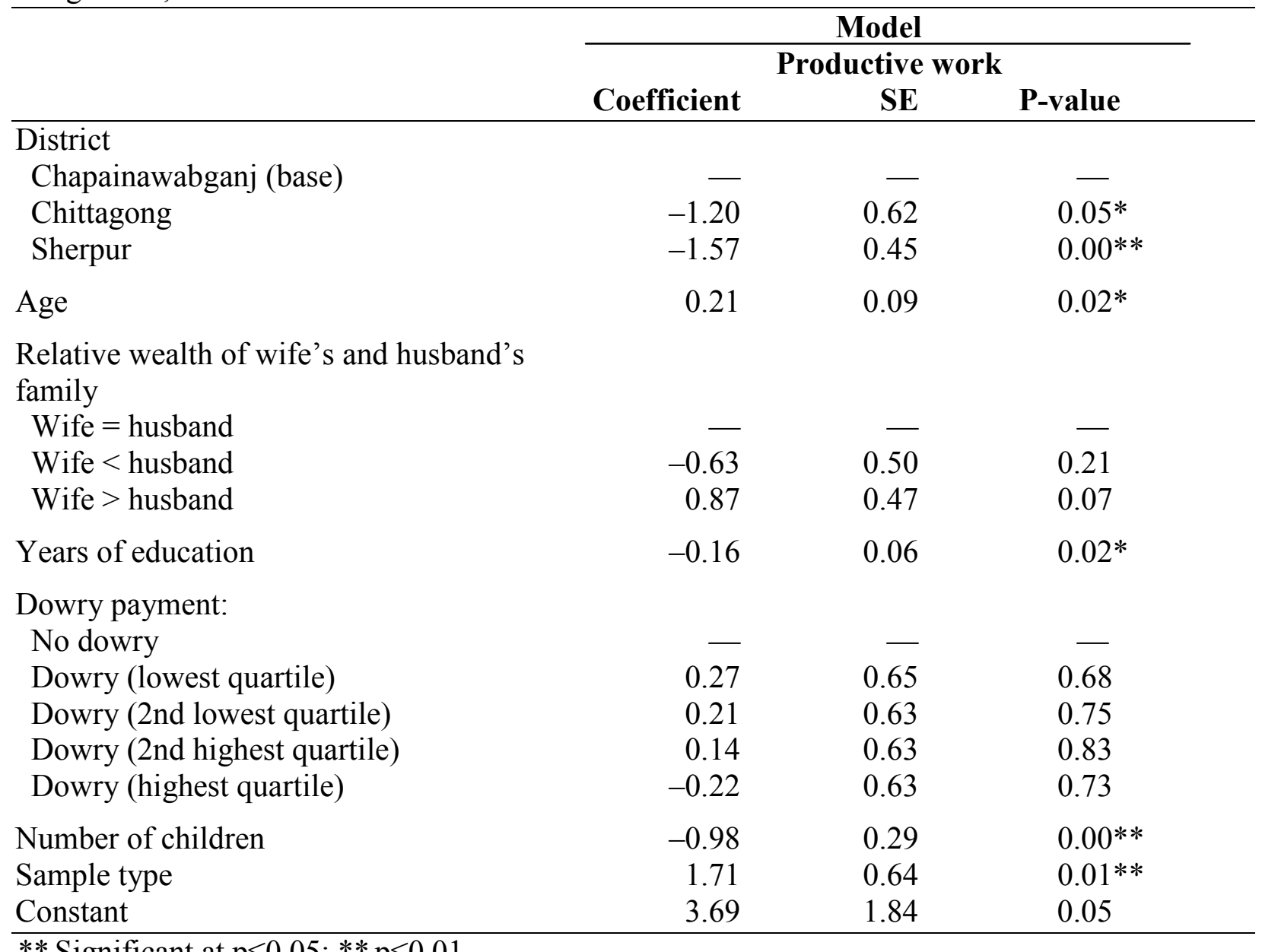


Table 5: Coefficient estimates from regression analysis of time spent in self-care, Bangladesh, 2003

\begin{tabular}{|c|c|c|c|}
\hline & \multicolumn{3}{|c|}{ Model } \\
\hline & \multicolumn{3}{|c|}{ Self-care } \\
\hline & Coefficient & SE & P-value \\
\hline \multicolumn{4}{|l|}{ District } \\
\hline Chapainawabganj (base) & - & - & - \\
\hline Chittagong & 1.68 & 0.87 & 0.06 \\
\hline Sherpur & -1.32 & 0.64 & $0.04 *$ \\
\hline Age & -0.19 & 0.13 & 0.15 \\
\hline \multicolumn{4}{|c|}{$\begin{array}{l}\text { Relative wealth of wife's and husband's } \\
\text { family }\end{array}$} \\
\hline Wife $=$ husband & - & - & - \\
\hline Wife $<$ husband & 0.97 & 0.71 & 0.17 \\
\hline Wife $>$ husband & -1.42 & 0.67 & $0.03 *$ \\
\hline Years of education & 0.29 & 0.09 & $0.00 * *$ \\
\hline \multicolumn{4}{|l|}{ Dowry payment: } \\
\hline No dowry & - & - & - \\
\hline Dowry (lowest quartile) & -1.05 & 0.92 & 0.25 \\
\hline Dowry (2nd lowest quartile) & -2.39 & 0.90 & $0.01 * *$ \\
\hline Dowry (2nd highest quartile) & -1.99 & 0.89 & $0.03 *$ \\
\hline Dowry (highest quartile) & -0.95 & 0.89 & 0.28 \\
\hline Number of children & -2.84 & 0.41 & $0.00 * *$ \\
\hline Sample type & 0.02 & 0.90 & 0.98 \\
\hline Constant & 28.46 & 2.60 & 0.00 \\
\hline
\end{tabular}

** Significant at $\mathrm{p} \leq 0.05 ; * * \mathrm{p} \leq 0.01$. 
Table 6: Multivariate regression analysis of time spent in domestic work, Bangladesh, 2003

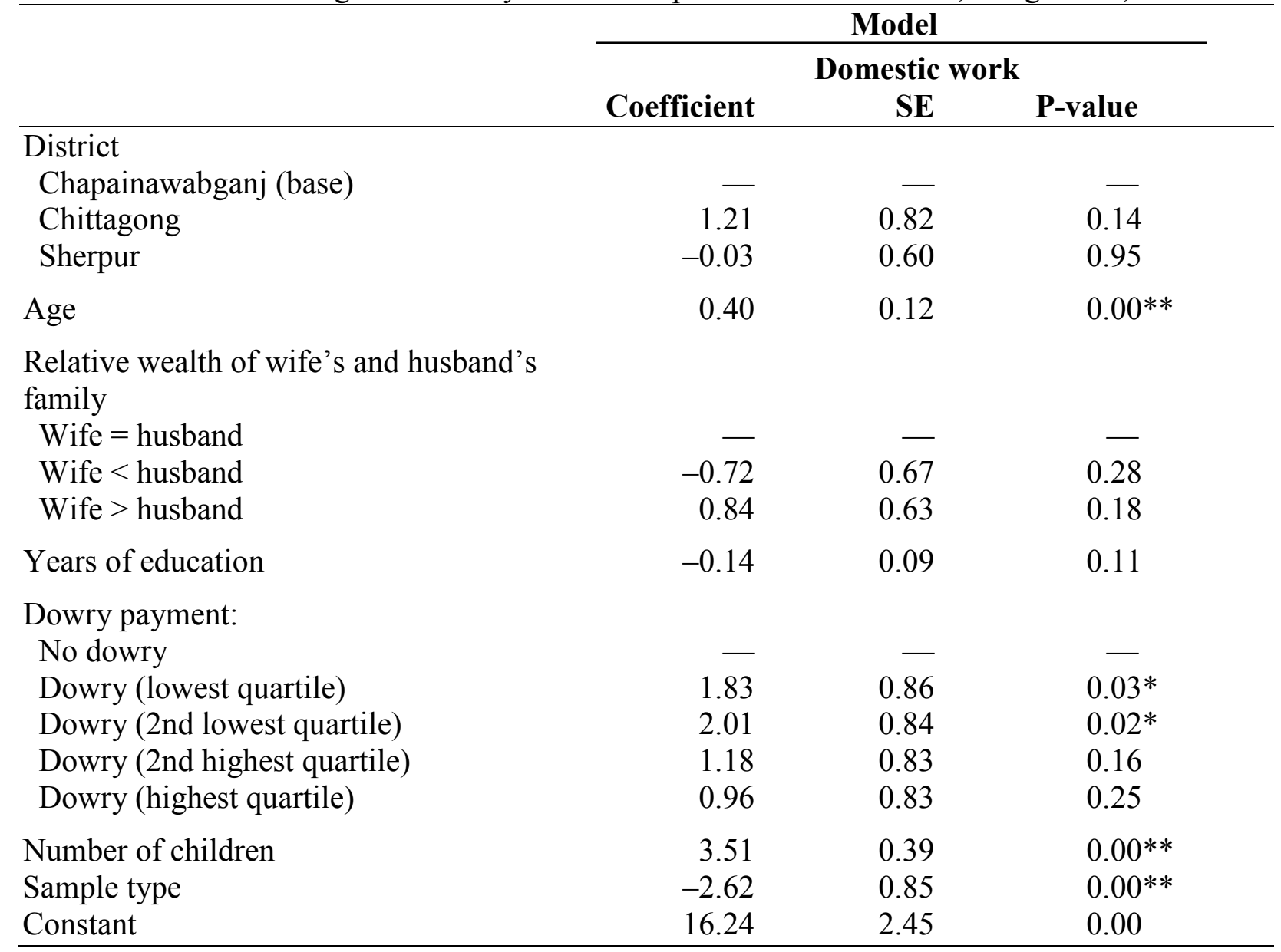

** Significant at $\mathrm{p} \leq 0.05 ; * * \mathrm{p} \leq 0.01$. 


\section{Poverty, Gender, and Youth Working Papers}

If still in print, single copies of up to three working papers from 1989 through 2003 are available free of charge.

Beginning with the 2004 issues, working papers are no longer available in print format. Instead they are distributed electronically. As each new paper is completed, subscribers are notified by e-mail and a link to the paper is provided.

To subscribe to the Poverty, Gender, and Youth working paper e-mail notification list, or to obtain back issues from 1989 to 2003, please send your request to pgywp@popcouncil.org.

PDFs of recent issues are available at www.popcouncil.org/publications/wp/index.html

2008

10 Sajeda Amin and Luciana Suran, "Terms of marriage and time-use patterns of young wives: Evidence from rural Bangladesh."

9 John Bongaarts, Thomas Buettner, Gerhard Heilig, and François Pelletier, "Has the HIV epidemic peaked?"

8 Barbara S. Mensch, Paul C. Hewett, Richard Gregory, and Stephane Helleringer, "Sexual behavior and STI/HIV status among adolescents in rural Malawi: An evaluation of the effect of interview mode on reporting."

7 John Bongaarts, "Fertility transitions in developing countries: Progress or stagnation?"

2007

6 Cynthia B. Lloyd, "The role of schools in promoting sexual and reproductive health among adolescents in developing countries."
5 Ann Biddlecom, Richard Gregory, Cynthia B. Lloyd, and Barbara S. Mensch, "Premarital sex and schooling transitions in four subSaharan African countries."

4 Sajeda Amin, John B. Casterline, and Laura Spess, "Poverty and fertility:

Evidence and agenda."

3 Bussarawan Teerawichitchainan and James F. Phillips, "Ethnic differentials in parental health seeking for childhood illness in Vietnam."

2 Zachary Zimmer, Kim Korinek, John Knodel, and Napaporn Chayovan, "Support by migrants to their elderly parents in rural Cambodia and Thailand: A comparative study."

1 Sharon Ghuman and Cynthia B. Lloyd, "Teacher absence as a factor in gender inequalities in access to primary schooling in rural Pakistan." 
Policy Research Division

working papers

2006

219 Cynthia B. Lloyd and Barbara S. Mensch, "Marriage and childbirth as factors in school exit: An analysis of DHS data from sub-Saharan Africa."

218 Ayaga A. Bawah, James F. Phillips, Martin Adjuik, Maya VaughanSmith, Bruce MacLeod, and Fred N. Binka, "The impact of immunization on the association between poverty and child survival: Evidence from Kassena-Nankana District of northern Ghana."

217 Zachary Zimmer, "Poverty, wealth inequality, and health among older adults in rural Cambodia."

216 John Bongaarts, "Late marriage and the HIV epidemic in sub-Saharan Africa."

215 John Bongaarts, "How long will we live?"

214 Zachary Zimmer, Toshiko Kaneda, and Laura Spess, "Urban versus rural mortality among older adults in China."

213 Paul Demeny and Geoffrey McNicoll, "The political demography of the world system, 2000-2050.”

212 Monica Grant and Kelly Hallman, "Pregnancy-related school dropout and prior school performance in South Africa."

211 Kelly Hallman, Sara Peracca, Jennifer Catino, and Marta Julia Ruiz, "Multiple disadvantages of Mayan females: The effect of gender, ethnicity, poverty, and residence on education in Guatemala."
210 Geoffrey McNicoll, "Policy lessons of the East Asian demographic transition."

209 Cynthia B. Lloyd, Cem Mete, and Monica J. Grant, "The implications of changing educational and family circumstances for children's grade progression in rural Pakistan: 19972004." 